\title{
Genetic differentiation of the neotropical tree species Protium spruceanum (Benth.) Engler (Burseraceae) between fragments and vegetation corridors in Brazilian Atlantic forest
}

\author{
Fábio de Almeida Vieira ${ }^{1,3}$ and Dulcinéia de Carvalho ${ }^{2}$
}

Received: January, 19, 2009. Accepted: May 18, 2009

\begin{abstract}
RESUMO - (Diferenciação genética da espécie arbórea neotropical Protium spruceanum (Benth.) Engler (Burseraceae) entre fragmentos e corredores de vegetação em floresta Atlântica Brasileira). Foram estudados os padrões de diferenciação genética em uma paisagem conectada com uma interessante história de conversão humana do habitat, que iniciou há dois séculos durante o período colonial do Brasil. Nos fragmentos de floresta estacional Atlântica e corredores de floresta secundária, Protium spruceanum é uma arbórea nativa abundante, com floração massiva, polinizada por insetos e dispersa por pássaros. A distribuição da diversidade genética foi analisada por meio de locos aloenzimáticos em 230 indivíduos em cinco fragmentos (1 a 11,8 ha) e quatro corredores (460 a $1000 \mathrm{~m}$ ). Foi observada ausência de endogamia nos fragmentos e corredores, mas a proporção de heterozigotos $(\hat{f})$ foi significativamente maior nos fragmentos do que nos corredores de vegetação secundária, conforme teste $G$ de Goudet $(P=0,036)$. A diferenciação genética foi baixa e nenhum padrão de isolamento pela distância foi observado. Observou-se, em geral, menor diferenciação genética entre fragmentos e corredores vizinhos, indicando possível fluxo gênico por sementes e pólen. Assim, conclui-se que os corredores de floresta secundária podem ser uma alternativa na conexão genética de fragmentos isolados. Isto é assim consistente com a baixa diferenciação observada entre eles e na ausência de uma redução significante da diversidade genética nos corredores de floresta secundária.
\end{abstract}

Palavras-chave: aloenzimas, diversidade genética, estatística- $F$, fragmentação de habitat

ABSTRACT - (Genetic differentiation of the neotropical tree species Protium spruceanum (Benth.) Engler (Burseraceae) between fragments and vegetation corridors in Brazilian Atlantic forest). We studied patterns of genetic differentiation in a connected landscape with an interesting history of human habitat conversion that began two centuries ago, during the Brazilian colonization period. In the fragments of Brazilian Atlantic seasonal forest and corridors of secondary forest, Protium spruceanum is an abundant native, mass-flowering/insect-pollinated and bird-dispersed tree. Genetic diversity was analyzed from 230 individuals in five fragments (1 to $11.8 \mathrm{ha}$ ) and four corridors (460 to $1000 \mathrm{~m}$ length) using allozyme loci. We did not find evidence of inbreeding within fragments or corridors, but the proportion of heterozygotes $(\hat{f})$ were significantly higher in fragments than in the secondary vegetation corridors, based on Goudet's $G$-test $(P=0.036)$. Genetic differentiation was low and no pattern of isolation by distance was detected. All fragments generally present low historical genetic differentiation with corridors that they are connected, indicating possible gene flow via seeds and pollen. Due to the consistently low differentiation observed among them and the absence of a significant reduction in gene diversity in second-growth forests, we conclude that corridors of second-growth forests would be an important alternative in the genetic connection of isolated forest fragments.

Key words: allozymes, $F$-statistics, genetic diversity, habitat fragmentation

\section{Introduction}

Many studies have reported the spatial patterns of genetic variation in a range of species with different life history characteristics and associated with landscape features, especially those related to recent human occupation (Manel et al. 2003; Lowe et al. 2005), to provide information on how landscape and environmental features influence population genetic structure (Storfer et al. 2007). Possible theoretical impacts generated by different types of human activity would suggest that forest loss and spatial isolation of natural populations can decrease levels of gene flow and reduce effective population size of a species in a region (Fahring 2003). If the remaining population is isolated for many generations, forest fragmentation may lead to continuous allele loss (Aldrich \& Hamrick 1998; Couvet 2002) and consequently, there will be an increase in the genetic divergence between these more isolated populations in the region (Pither et al. 2003). In contrast, some studies have shown that habitat fragmentation facilitated both pollen flow (White et al. 2002; Dick et al. 2003) and long-distance dispersal (Bacles et al. 2006). Thus, the effects of habitat fragmentation on the genetic behaviour of tree populations are more varied and complex than first expected (Aldrich \& Hamrick 1998; Lowe et al. 2005).

Studies at landscape-level scales provide insight into micro-evolutionary patterns by elucidating the movement of genes at a range of spatial scales (Manel et al. 2003; Storfer et al. 2007). Several studies have evaluated the landscape context in secondary forest (Aldrich \& Hamrick 1998; Hamilton 1999; Sezen et al. 2005; Ally \& Ritland 2007), but few works have estimated the role of corridors and landscape connectivity for plants (Debinski \& Holt 2000), instead tending to focus primarily on genetic processes (Kirchner et al. 2003). For second-growth forests, population genetic studies indicate bottlenecks, through reproductive dominance, reduced genetic diversity of a founder population and increased levels of inbreeding (Aldrich \& Hamrick 1998; Sezen et al. 2005). Hence tree populations in secondgrowth forests will require continuous gene flow over successive generations to restore genetic diversity to levels currently observed in older more established forests (Sezen et al. 2005). Alternatively, corridors have been proposed as one way to mediate the effects of habitat fragmentation on populations (Beier \& Noss 1998; Nasi et al. 2008). Some studies have provided convincing evidence that, in

\footnotetext{
Universidade Federal do Rio Grande do Norte, Departamento de Agropecuária, 59072-970 Natal, RN, Brazil

Universidade Federal de Lavras, Departamento de Ciências Florestais, 37200-000 Lavras, MG, Brazil

Corresponding author: vieirafa@yahoo.com.br
} 
some cases, corridors can enhance migration rates among fragments (Aars \& Ims 1999; Mech \& Hallet 2001).

The aim of this study was to verify the patterns of genetic differentiation between fragments and vegetation corridors in a landscape with an interesting history of human habitat conversion. The Brazilian Atlantic forest, in southern Minas Gerais state, has been seriously exploited since European occupation two centuries ago. This exploitation resulted in the fragmentation and isolation of these populations at a particularly rapid pace. The detection of recent genetic bottlenecks also corroborates historical evidence that the forest fragments were once part of a much larger population and can be interpreted as a consequence of the habitat fragmentation resulting from the Brazilian colonization period (Vieira \& Carvalho 2008). At the same time, ditches to divide rural properties ( $\approx 6 \mathrm{~m}$-wide) were constructed by slaves, resulting in the vegetation corridors, i.e., secondgrowth colonization by native tree species that connect small fragments of forest. We focused on the following questions: (1) Is there significant differentiation among fragments and vegetation corridors according to genetic parameters (i.e. heterozygosities and fixation index)? (2) Do fragments present low historical genetic differentiation $\left(F_{S T}\right)$ with corridors that they are connected? (3) Is there the association between genetic and geographic distances among fragments?

We used allozyme markers that have been successfully used to address the questions about genetic effects of habitat fragmentation on tree species (Hall et al. 1996; Fuchs et al. 2003; Franceschinelli et al. 2007). Protium spruceanum was chosen for this research as highly representative of a broad range of taxa with a common suite of ecological characteristics for tropical trees in the study region: high population density, mass-flowering, insect-pollinated and bird-dispersed tree species. We hypothesized that patterns of genetic variation in fragments should reflect the expectation for a species typically outcrossing, namely high levels of genetic variation within and relatively low levels of differentiation between fragment populations. If seed dispersal and pollen movement is widespread relative to the distance between fragments the result should be an undetected spatial genetic structure by isolation by distance model. Finally, theoretical predictions suggest reduced genetic diversity and increased levels of inbreeding in corridors of second-growth forests.

\section{Materials and methods}

Study species - Protium spruceanum (Benth.) Engler (Burseraceae) is a large canopy tree (up to $25 \mathrm{~m}$ tall) occurring in the Amazon and the Atlantic rain forests and on the Cerrado inside riverbank woodland (Oliveira Filho $\&$ Ratter 1995). The recruitment of seedlings may occur under large trees, since $P$. spruceanum is shade-tolerant. The small, pale yellowish flowers (0.3-0.4 cm wide) are functionally unisexual and organized in dense inflorescences (with ca. 45 flowers) and the individuals are dioecious. The effective pollinators are Apis mellifera and Trigona sp. (Hymenoptera, Apidae) (F. A. Vieira et al., unpublished data, 2009). The medium-sized, bird-dispersed seeds $(<500 \mathrm{mg}$ fresh weight $)$ are produced in reddish berries in the canopy of adult trees and are dispersed from October to March, with a peak in November (F. A. Vieira et al., unpublished data, 2009). In the fragment-corridor system studied $P$. spruceanum along with other tree species such as Tapirira guianensis Aublet (Anacardiaceae), Copaifera langsdorffii Desf. (Fabaceae), Ocotea pulchella Mart. (Lauraceae) and the congeners $P$. widgrenii Engler and P. heptaphyllum (Aublet) Marchand (Burseraceae), represent the most abundant species of a mass-flowering/ insect-pollinated and bird-dispersed tree species.

Study site and sampling design - The fragment-corridor system studied is located in the region of Lavras, southern Minas Gerais state in Brazil (Fig. 1). In the current landscape a limited number of fragments, a matrix of planted pastures and vegetation corridors of secondary forest can be observed. The populations analyzed have rapidly declined because of habitat fragmentation caused by anthropogenic disturbance over the last 200 y (Vieira \& Carvalho, 2008). Hence the estimated age of the trees is 2-4 generations before present, assuming a generation time of 50-100 y. Five interlinking fragments and a vegetation corridor were analyzed (Tab. 1). P. spruceanum presence in fragments F2, F3 and F4 coincides with the presence of water courses, in F1 and F5 the species occurs in a large area of the fragment that may be attributed to semi-permanently flooded soil. All samples came from trees with diameter at breast height $(\mathrm{dbh})>20 \mathrm{~cm}$ and $\approx 16 \mathrm{~m}$ in height from the interior of each fragment within an area of about 1 to 11.8 ha. Sampling in each corridor was along the length of each corridor axis of about 460 to $1000 \mathrm{~m}$.
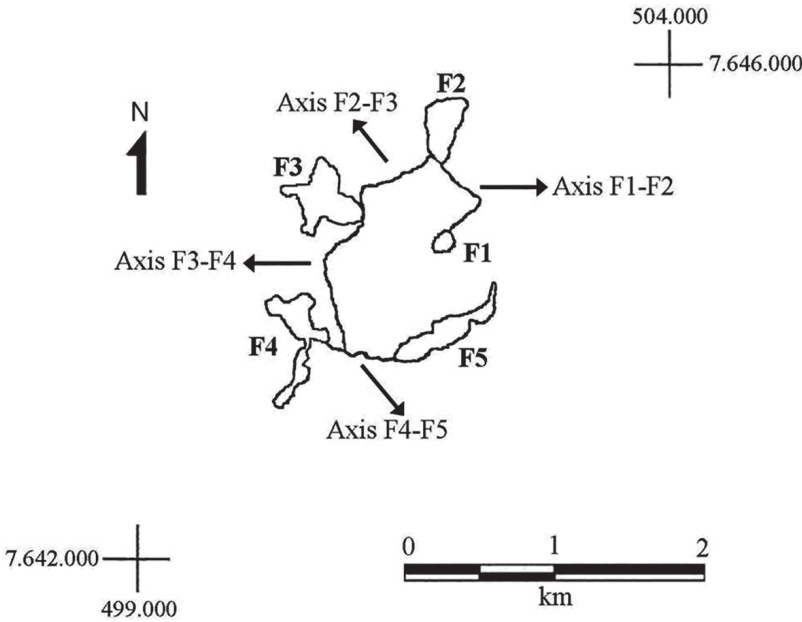

Figure 1. Location of the study system with forest fragments and secondary vegetation corridors in Minas Gerais state, Brazil. F1 to F5 (fragments) and Axis F1-F2 to F4-F5 (vegetation corridors). The coordinates are according to the Universal Transverse Mercator (UTM) system.

Enzyme extraction and electrophoresis - Enzymes were extracted from $200 \mathrm{mg}$ of frozen leaf tissue in $1 \mathrm{~mL}$ of phosphate extraction buffer: 0.2 $\mathrm{mM}$ sucrose, $2.5 \%$ polyvinylpyrrolidone (PVP), $1 \mathrm{mM}$ ethylenediaminetetraacetic acid (EDTA), $5.7 \mathrm{mM}$ ascorbic acid, $5.8 \mathrm{mM}$ sodium diethyl carbamate (DIECA), $2.6 \mathrm{mM}$ sodium bisulphite, $2.5 \mathrm{mM}$ Borax and $0.2 \%$ $\beta$-mercaptoethanol. Discontinuous vertical electrophoresis in a polyacrylamide gel was performed using $10 \%$ page gels and carried out at $4{ }^{\circ} \mathrm{C}$ over $3 \mathrm{~h}$ (constant current of $80 \mathrm{~mA}$, and voltage of $300 \mathrm{~V}$ ). Eight enzymatic systems were used: alcohol dehydrogenase (E.C.1.1.1.1, locus $A d h$ ), glucose dehydrogenase (E.C.1.1.1.47, locus $G d h$ ), $\beta$-galactose dehydrogenase (E.C.1.1.1.48, locus Gldh), glutamate dehydrogenase (E.C.1.4.1.3, locus $G t d h)$, malate dehydrogenase (E.C.1.1.1.37, loci $M d h-1$ and $M d h-2)$, peroxidase (E.C.1.11.1.7, loci Per-1 and Per-2), sorbitol dehydrogenase (E.C.1.1.1.14, locus $S d h$ ) and shikimate dehydrogenase (E.C.1.1.1.25, locus $S k d h$ ). Staining protocols and the genetic basis of allozymes banding patterns were inferred from segregation patterns with reference to typical subunit structure and conceptual methods (Wendel \& Weeden 1989). Putative loci and alleles were designated sequentially. The most anodally migrating allozyme or alleles was designated as 1 and the next as 2 .

Data analyses - The genetic variation within each population was estimated by the proportion of polymorphic loci $\left(P_{L} ; 0.95\right.$ criterion), 
Table 1. Fragments and corridor codes, area of the fragments and length of the vegetation corridors, sample size ( $N$ ), density of Protium spruceanum (Benth.) Engler and genetic variation in populations sampled in this study. $\hat{H}_{o}$, mean observed heterozygosity (standard error); $\hat{H}_{e}$, mean gene diversity (standard error); $\hat{f}$, mean fixation index. In the vegetation corridor the absolute density of the species is 135 trees ha-1 $\left(\mathrm{G}\right.$. C. de Castro, unpublished data). ${ }^{*} P<0.05$.

\begin{tabular}{|c|c|c|c|c|c|c|c|c|c|}
\hline \multirow[b]{2}{*}{ Code } & \multicolumn{5}{|c|}{ Fragments } & \multicolumn{4}{|c|}{ Corridors } \\
\hline & F1 & F2 & F3 & F4 & F5 & F1-F2 & F2-F3 & F3-F4 & F4-F5 \\
\hline Area (ha) & 1 & 7.2 & 11.8 & 7.4 & 7.8 & & & & \\
\hline Length (m) & & & & & & 650 & 460 & 1000 & 540 \\
\hline$N$ & 30 & 30 & 30 & 30 & 30 & 20 & 20 & 20 & 20 \\
\hline Density ha ${ }^{-1}$ & 850 & 50 & 8.3 & 175 & 175 & & & & \\
\hline$\hat{H}_{o}$ & $\begin{array}{c}0.559 \\
(0.070)\end{array}$ & $\begin{array}{c}0.552 \\
(0.069)\end{array}$ & $\begin{array}{c}0.475 \\
(0.071)\end{array}$ & $\begin{array}{c}0.477 \\
(0.038)\end{array}$ & $\begin{array}{c}0.630 \\
(0.072)\end{array}$ & $\begin{array}{c}0.419 \\
(0.106)\end{array}$ & $\begin{array}{c}0.392 \\
(0.100)\end{array}$ & $\begin{array}{c}0.376 \\
(0.103)\end{array}$ & $\begin{array}{c}0.483 \\
(0.044)\end{array}$ \\
\hline$\hat{H}_{e}$ & $\begin{array}{c}0.480 \\
(0.016)\end{array}$ & $\begin{array}{c}0.469 \\
(0.015)\end{array}$ & $\begin{array}{c}0.381 \\
(0.065)\end{array}$ & $\begin{array}{c}0.437 \\
(0.027)\end{array}$ & $\begin{array}{c}0.507 \\
(0.002)\end{array}$ & $\begin{array}{c}0.454 \\
(0.050)\end{array}$ & $\begin{array}{c}0.383 \\
(0.071)\end{array}$ & $\begin{array}{c}0.336 \\
(0.094)\end{array}$ & $\begin{array}{c}0.470 \\
(0.041)\end{array}$ \\
\hline$\hat{f}$ & -0.170 & -0.182 & $-0.250 *$ & -0.093 & $-0.248^{*}$ & 0.078 & -0.023 & -0.123 & -0.029 \\
\hline
\end{tabular}

mean number of alleles per locus $(\hat{A})$, observed heterozygosity $\left(\hat{H}_{o}\right)$ and Nei's gene diversity $\left(\hat{H}_{e}\right)$. Deviations from Hardy-Weinberg expectations were examined for each population by calculating Wright's fixation index $\left(\hat{f}=1-\hat{H}_{o} / \hat{H}_{e}\right)$. All these parameters were calculated using BIOSYS 2 (Swofford \& Selander 1989) and GDA programs (Lewis \& Zaykin 2001). Wright's $F$-statistics ( $\hat{f}$ and $\hat{F}$, Wright 1943) were used to measure hierarchical population structure and were calculated by the methods of Weir and Cockerham (1984). Confidence intervals at $95 \%$ probability were established for each population using the bootstrap procedure with 10000 repetitions. These parameters were estimated using the program GDA. Comparisons among fragments and corridors according to these parameters $\left(\hat{H}_{o}, \hat{H}_{e}\right.$ and $\left.\hat{f}\right)$, were made using the program FSTAT 2.9.3.2 (Goudet 2002), through the $G$-based exact test by randomization of multilocus genotypes for allozymes proposed by Goudet et al. (1996).

We calculated pairwise differentiation between fragments and fragments and corridors using $F_{S T}$ statistics (Weir \& Cockerham 1984). Pairwise tests of differentiation were performed using the $G$-test, based on 3600 permutations of genotypes among samples (Goudet et al. 1996). Significance tests of multilocus pairwise $F_{S T}$ were carried out using the program FSTAT with standard Bonferroni corrections. To test for isolation by distance, pairwise $\left(F_{S T} / 1-F_{S T}\right)$ matrices were related to geographical distances between fragments. Mantel tests were used to test for significance (1000 permutations) with the software NTSYS 1.5 program (Rohlf 1989).

\section{Results}

Genetic diversity - Ten polymorphic loci and twenty alleles were observed and analyzed. The percentage of polymorphic loci $\left(P_{L}=100 \%\right)$ and average number of alleles per locus $(\hat{A}=2.0)$ were similar for all populations. The negative Wright's $F$-statistics indicated the excess of heterozygotes for the fragments and corridors (Tab. 2). The relationship between the observed $\hat{H}_{o}$ and expected $\hat{H}_{e}$ mean heterozygosities resulted in a significant heterozygosity excess $f$ for fragments (Tab. 2). Based on Goudet's $G$-test, the mean value of observed heterozygosities $(P=0.044)$ and fixation index $(P=0.036)$ were significantly higher in fragments than corridors. The mean value of gene diversity was not significantly different between fragments and corridors $(P=0.242)$.

Genetic differentiation between fragments and corridors - Specific genetic differentiation was low, the $\hat{F}_{S T}$ value of 0.028 suggesting that only $2.8 \%$ of the genetic variability is distributed between fragments, and that $97.2 \%$ of the variability occurs within fragments. The genetic differentiation in each forest fragment pair (Tab. 3) and for each fragment and corridor pair (Tab. 4) generally was low. The highest genetic differentiation was between F3 and F5 forest fragments, corroborated by significant tests of population differentiation pairwise $\left(\hat{F}_{S T}=0.111, P<0.001\right)$ after Bonferroni correction (Tab. $3)$. Fragment $\mathrm{F} 3$ revealed low genetic differentiation with fragment F2 (these two are connected by the F2$\mathrm{F} 3$ corridor). Indeed, fragment F3 present low genetic differentiation exactly with the F2-F3 axis (Tab. 4). Generally the fragments have low genetic differentiation with corridors that they are connected. The highest observed genetic differentiation occurred between fragment F5 and F2-F3 $\left(\hat{F}_{S T}=10.5 \%, P<0.001\right)$ and F3-F4 axis $\left(\hat{F}_{S T}=14.8 \%, P<0.001\right)$, at $5 \%$ level. Mantel tests provided no evidence for distance dependence of genetic structure $\left(r_{m}=-0.051, P=0.539\right)$.

Table 2. Allelic frequencies (allele 1 ) for 10 allozyme loci and genetic diversity parameters for Protium spruceanum (Benth.) Engler in the fragment-corridor system. $\hat{H}_{o}$, mean observed heterozygosity (standard error); $\hat{H}_{e}$, mean gene diversity (standard error); $\hat{f}$, mean fixation index; $\hat{F}$, mean overall inbreeding coefficient. $* P<0.05$.

\begin{tabular}{crr}
\hline & Fragment & \multicolumn{1}{c}{ Corridor } \\
\hline Locus/Allelic frequencies & & \\
Adh & 0.650 & 0.744 \\
Gdh & 0.654 & 0.714 \\
Gtdh & 0.648 & 0.706 \\
Mdh-1 & 0.642 & 0.744 \\
$M d h-2$ & 0.573 & 0.606 \\
$P e r-1$ & 0.641 & 0.744 \\
$P e r-2$ & 0.620 & 0.690 \\
$S d h$ & 0.647 & 0.600 \\
$S k d h$ & 0.647 & 0.712 \\
Genetic diversity & 0.629 & 0.714 \\
$\hat{H}_{o}$ & & -0.018 \\
$\hat{H}_{e}$ & $0.538(0.008)$ & $0.418(0.021)$ \\
$\hat{f}$ & $0.463(0.004)$ & $0.420(0.012)$ \\
$\hat{F}$ & $-0.188^{*}$ & -0.010 \\
\hline
\end{tabular}


Table 3. Geographical distances (km, above diagonal) and genetic differentiation $\left(\hat{F}_{S T}\right.$ values, below diagonal) among five fragments. $* P$-value $<0.001 ;$ NS, nonsignificant at $5 \%$ level.

\begin{tabular}{llllll}
\hline Fragments & F1 & F2 & F3 & F4 & F5 \\
\hline F1 & - & 0.94 & 0.88 & 1.19 & 0.81 \\
F2 & $0.007^{\text {ns }}$ & - & 1.00 & 2.00 & 1.75 \\
F3 & $0.048^{\text {ns }}$ & $0.019^{\text {ns }}$ & - & 1.25 & 1.38 \\
F4 & $0.002^{\text {ns }}$ & $0.008^{\text {ns }}$ & $0.007^{\text {ns }}$ & - & 0.81 \\
F5 & $0.010^{\text {ns }}$ & $0.024^{\text {ns }}$ & $0.111^{*}$ & $0.053^{\text {ns }}$ & - \\
\hline
\end{tabular}

Table 4. Genetic differentiation $\left(\hat{F}_{S T}\right)$ among forest fragments and secondary vegetation corridors. Estimates obtained and tests performed using FSTAT 2.9.3.2 (Goudet 2002). NS, non-significant at 5\% level.

\begin{tabular}{ccc}
\hline Fragments/corridors & $\hat{F}_{S T}$ & $P$ \\
\hline F1 and F1-F2 & 0.003 & NS \\
F1 and F2-F3 & 0.036 & NS \\
F1 and F3-F4 & 0.071 & $<0.01$ \\
F1 and F4-F5 & 0.013 & NS \\
F2 and F1-F2 & 0.009 & NS \\
F2 and F2-F3 & 0.015 & NS \\
F2 and F3-F4 & 0.049 & NS \\
F2 and F4-F5 & 0.004 & NS \\
F3 and F1-F2 & 0.014 & NS \\
F3 and F2-F3 & 0.003 & NS \\
F3 and F3-F4 & 0.020 & NS \\
F3 and F4-F5 & 0.051 & NS \\
F4 and F1-F2 & 0.007 & NS \\
F4 and F2-F3 & 0.001 & NS \\
F4 and F3-F4 & 0.026 & NS \\
F4 and F4-F5 & 0.002 & NS \\
F5 and F1-F2 & 0.040 & NS \\
F5 and F2-F3 & 0.105 & $<0.001$ \\
F5 and F3-F4 & 0.148 & $<0.001$ \\
F5 and F4-F5 & 0.018 & NS \\
Overall & 0.028 & \\
\hline & &
\end{tabular}

\section{Discussion}

Genetic diversity in Protium spruceanum - The number of alleles per locus $(\hat{A})$ was similar to with values of other tropical plants. Hamrick \& Godt (1989), in a review of 653 genetic diversity studies using allozymes, described the following values of $\hat{A}: 2.19$ for woody long-lived species, 2.29 for widely distributed species, 1.81 for tropical species and 1.99 for allogamous animal-pollinated species. The gene diversity $\hat{H}_{e}$ detected within forest fragments and secondary vegetation corridors was higher than the value estimated for tree species in general $\left(\hat{H}_{e}=0.17\right.$, Hamrick \& Godt 1989) and also higher for some tropical tree species, in recent studies using allozymes markers $\left(\hat{H}_{e}=0.25\right.$ for Acacia macracantha and $\hat{H}_{e}=0.24$ for $A$. aroma, Casiva et al. 2004; $\hat{H}_{e}=0.13$ for Pithecellobium elegans, Hall et al. 1996), otherwise is close to the other tropical tree species $\left(\hat{H}_{e}=0.40\right.$ in Pachira quinata, Fuchs et al. 2003; $\hat{H}_{e}=0.49$ in Shorea leprosula, $\mathrm{Ng}$ et al. 2004). The high gene diversity detected is likely to be associated with the reproductive system and demography of populations (Murawski \& Hamrick 1991; Nason \& Hamrick 1997).
For P. spruceanum, besides the high population density, the functionally unisexual flowers in different individuals flower synchronously, favoring outcrossing (F. A. Vieira et al., unpublished data, 2009). Indeed, the population size effect on population genetic diversity might be pronounced mainly in outcrossing species (Honnay \& Jacquemyn 2007) and outcrossing plants in general exhibit higher levels of gene diversity than selfing plants (Hamrick \& Godt 1996). Density has also been observed to influence rates of outright outcrossing in animal-pollinated plant species showing a positive association (Loveless \& Hamrick 1984; van Treuren et al. 1993). Moreover, compared with endemic and rare taxa, widespread and abundant species often present significantly more genetic variability (Cole 2003).

Although the mean value of gene diversity was not significantly different between fragments and corridors, through the $G$-based exact test, observed heterozygosities and fixation index were significantly higher in fragments than secondary vegetation corridors. The estimates indicate that a higher proportion of heterozygotes are found in the fragments than in the secondary vegetation corridors. However, given the longevity of most tree species, the a study of the next generations will be required to provide a clear picture of the genetic fate of the studied populations.

Genetic differentiation - For an insect-pollinated and bird-dispersed tree, low genetic differentiation among forest fragments was expected and observed $\left(\hat{F}_{S T}=0.028\right)$. This is in accordance with other tropical tree species, i.e., most genetic variability is detected within populations (Hall et al. 1996; Dayanandan et al. 1999). The low genetic differentiation estimated is probably the result, amongst other factors, of the population size and consequential massive annual flowering, featuring quick and well-synchronized blooming peaks of unisexual flowers (F. A. Vieira et al., unpublished data, 2009). Mass flowering represents the most extreme example of flowering synchrony at both the individual and population level (Frankie et al. 1974; Gentry 1978). Flowering synchrony can influence the levels of gene flow and differentiation among populations (Soliva \& Widmer 1999) depending on the effects of other organisms such as pollinators and seed dispersers (Domínguez et al. 2005). Studies have shown that in highly disturbed habitats Apis mellifera may expand genetic neighbourhood areas, thereby linking fragmented habitats (Dick et al. 2003). So, large pasture trees and vegetation corridors will play an important 
role as genetic stepping-stones, providing also roosting sites for frugivorous birds.

Although the value of genetic differentiation detected for P. spruceanum is consistent with that expected for outcrossing species (Hamrick \& Godt 1996), it should be noted that genetic differentiation occurred among populations located at an average distance of only $1.2 \mathrm{~km}(0.81$ to $2 \mathrm{~km})$, and even those populations located as close as $1.38 \mathrm{~km}$ to each other (F3 and F5) showed significant differentiation. This result may be unexpected for a species typically outcrossing, pollinated by bees that are able to fly long distances and whose fruits are bird dispersed. Nevertheless, the genetic diversity levels may depend on factors (e.g. population size, environmental heterogeneity, even random patterns) including the landscape structure (Manel et al. 2003). Hence we combine genetic differentiation and distance between fragments, but no pattern of isolation by distance was observed. Generally all fragments have low historical genetic differentiation with corridors that they are connected, indicating possible gene flow via seeds and pollen.

Conclusions and prospects - Changes in gene flow can be estimated by comparing 'historical' estimates based on genetic differentiation $\left(\hat{F}_{S T}\right)$. Hence, indirect estimates of gene flow reflect historical rates of flow that have occurred over many generations (Loveless 1992). Typically outcrossing species display high within-population genetic diversity and low interpopulation genetic differentiation as a result of intense interpopulation gene flow (Loveless \& Hamrick 1984). Indeed, indirect estimates of gene flow revealed extensive gene exchange over the spatial scale of the study $\left(F_{S T}=2.8 \%\right)$, with high levels of genetic variation remaining across all fragments $\left(\hat{H}_{e}=0.463\right)$. However, a study of the next generations (i.e. young cohorts) will be required to provide a clear picture of the genetic outcome of the studied populations.

Nevertheless, considering the practically irreversible fragmentation of populations and the high genetic diversity detected in small forests, landscape management strategies should consider the protection of extant ones. Small-sized forest fragments have been reported as habitats or steppingstones for birds, and thus contribute to the connection of forest fragments (Estrada et al. 2000; Fischer \& Lindenmayer 2002). In addition, new approaches by studying other species with different life history characteristics would be needed to investigate the functional aspect of connectivity as it relates to the biological response of the species to landscape structure. Investigations on contemporary patterns (DNAbased) of genetic structure within populations, e.g. at fine-scale spatial genetic structure, also is necessary. These current ideas and researches are now in progress. This paper gives us important baseline data that will be useful in future comparisons of other common insect-pollinated and birddispersed Atlantic forest tree species as well as comparisons of other fragmented forests that are not connected by corridors of natural vegetation.

\section{Acknowledgements}

The authors acknowledge Anderson M. de Souza for assistance on the collection of samples, Dr. Cecile F.E. Bacles (University of QueenslandAustralia), Dr. Henk W.M. Hilhorst (Wageningen University-The Netherlands) and Dr. Dion Devey (Royal Botanic Kew Gardens) for their helpful comments on the manuscript. The Coordenação de Aperfeiçoamento de Pessoal de Nível Superior (CAPES) and the Conselho Nacional de Pesquisa $(\mathrm{CNPq})$ are also ackowledged for providing a Dr. fellowship for F. A. Vieira, a research fellowship for Dr. Dulcinéia de Carvalho and research grant. This research was support by FAPEMIG (Fundação de Amparo à Pesquisa do Estado de Minas Gerais).

\section{References}

Aldrich, P. R. \& Hamrick, J. L. 1998. Reproductive dominance of pasture trees in a fragmented tropical forest mosaic. Science 281: 103-105.

Ally, D. \& Ritland, K. 2007. A case study: looking at the effects of fragmentation on genetic structure in different life history stages of old-growth Mountain Hemlock (Tsuga mertensiana). Journal of Heredity 98: 73-78.

Aars, J. \& Ims, R. A. 1999. The effect of habitat corridors on rates of transfer and interbreeding between vole demes. Ecology 80: 1648-1655.

Bacles, C. F. E.; Lowe, A. J. \& Ennos, R. A. 2006. Effective seed dispersal across a fragmented landscape. Science 311: 628.

Beier, P. \& Noss, R. F. 1998. Do habitat corridors provide connectivity? Conservation Biology 12: 1241-1252.

Casiva, P. V.; Vilardi, J. C.; Cialdella, A. M. \& Saidman, B. O. 2004. Mating system and population structure of Acacia aroma and Amacracantha (Fabaceae). American Journal of Botany 91: 58-64.

Cole, C. T. 2003. Genetic variation in rare and common plants. Annual Review of Ecology Evolution and Systematics 34: 213-237.

Couvet, D. 2002. Deleterious effects of restricted gene flow in fragmented populations. Conservation Biology 16: 369-376.

Dayanandan, S.; Dole, J.; Bawa, K. \& Kesseli, R. 1999. Population structure delineated with microsatellite markers in fragmented populations of a tropical tree Carapa guianensis (Meliaceae). Molecular Ecology 8: $1585-1592$.

Debinski, D. E. R. \& Holt, D. 2000. A survey and overview of habitat fragmentation experiments. Conservation Biology 14: 342-355.

Dick, C. W.; Etchelecu, G. \& Austerlitz, F. 2003. Pollen dispersal of tropical trees (Dinizia excelsa, Fabaceae) by native insects and African honeybees in pristine and fragmented Amazonian rainforest. Molecular Ecology 12: 753-764.

Domínguez, C. A.; Abarca, C. A.; Eguiarte, L. E. \& Molina-Freaner, F. 2005. Local genetic differentiation among populations of the massflowering tropical shrub Erythroxylum havanense (Erythroxylaceae) New Phytologist 166: 663-672.

Estrada, A.; Cammarano, P. \& Coates-Estrada, R. 2000. Bird species richness in vegetation fences and in strips of residual rain forest vegetation at Los Tuxtlas Mexico. Biodiversity and Conservation 9: 1399-1416.

Fahring, L. 2003. Effects of fragmentation on biodiversity. Annual Review of Ecology and Systematics 34: 487-515.

Fischer, J. \& Lindenmayer, D. B. 2002. The conservation value of paddock trees for birds in a variegated landscape in southern New South Wales 2. Paddock trees as stepping stones. Biodiversity and Conservation 11: 833-849.

Franceschinelli, E. V.; Vasconcelos, G. M. P.; Landau, E. C.; Ono, K. Y. \& Santos, F. A. M. 2007. The genetic diversity of Myrciaria floribunda (Myrtaceae) in Atlantic Forest fragments of different sizes. Journal of Tropical Ecology 23: 361-367.

Frankie, G. W.; Baker, H. G. \& Opler, P. A. 1974. Comparative phenological studies of trees in tropical wet and dry forests in the lowlands of Costa Rica. Journal of Ecology 62: 881-919.

Fuchs, E. J.; Lobo, J. A. \& Quesada, M. 2003. Effects of forest fragmentation and flowering phenology on the reproductive success and mating patterns of the tropical dry forest tree Pachira quinata. Conservation Biology 17: 149-157.

Gentry, A. H. 1978. Antipollinators for mass-flowering plants? Biotropica 10: $68-69$. 
Goudet, J.; Raymond, M.; De Meuus, T. \& Rousset, F. 1996. Testing differentiation in diploid populations. Genetics 144: 1933-1940.

Goudet, J. 2002. FSTAT, a program to estimate and test gene diversities and fixation indices, Version 2.9.3.2, 2002.

Hall, P.; Walker, S. \& Bawa, K. S. 1996. Effect of forest fragmentation on genetic diversity and mating system in a tropical tree Pithecellobium elegans. Conservation Biology 10: 757-768.

Hamilton, M. B. 1999. Tropical tree gene flow and seed dispersal. Nature 402: 604.

Hamrick, J. L. \& Godt, M. T. 1989. Allozyme diversity in plant species. In: Brow A.H.D. et al (eds) Plant population genetics, breeding and genetic resources. Sinauer Associates, Sunderland, MA, pp 43-63.

Hamrick, J. L. \& Godt, M. J. W. 1996. Effects of life history traits on genetic diversity in plant species. Philosophical Transactions of the Royal Society of London, Series B 351: 1291-1298.

Honnay, O. \& Jacquemyn, H. 2007. Susceptibility of common and rare plant species to the genetic consequences of habitat fragmentation. Conservation Biology 21: 823-831.

Kirchner, F.; Ferdy, J.-B.; Andalo, C.; Moret, B. \& Colas, J. 2003. Role of corridors in plant dispersal: an example with the endangered Ranunculus nodiflorus. Conservation Biology 17: 401-410.

Lewis, P. O. \& Zaykin, D. 2001. Genetic data analysis: Computer program for the analysis of allelic data. Version 1.0 (d16c).

Loveless, M. D. 1992. Isozyme variation in tropical trees: patterns of genetic organization. New Forestry 6: 67-94

Loveless, M. D. \& Hamrick, J. L. 1984. Ecological determinants of genetic structure in plant populations. Annual Review of Ecology and Systematics 15: 65-95.

Lowe, A. J.; Boshier, D.; Ward, M.; Bacles, C. F. E. \& Navarro, C. 2005. Genetic resource impacts of habitat loss and degradation; reconciling empirical evidence and predicted theory for neotropical trees. Heredity 95: 255-273.

Manel, S.; Schwartz, M. K.; Luikart, G. \& Taberlet, P. 2003. Landscape genetics: combining landscape ecology and population genetics Trends in Ecology and Evolution 18: 189-197.

Mech, S. G. \& Hallett, J. G. 2001. Evaluating the effectiveness of corridors: a genetic approach. Conservation Biology 15: 467-474.

Murawski, D. A. \& Hamrick, J. L. 1991. The effect of the density of flowering individuals on the mating systems of nine tropical tree species. Heredity 67: 167-174.

Nasi, R.; Koponen, P.; Poulsen, J. G.; Buitenzorgy, M. \& Rusmantoro, W. 2008. Impact of landscape and corridor design on primates in a large-scale industrial tropical plantation landscape. Biodiversity and Conservation 17: 1105-1126.
Nason, J. D. \& Hamrick, J. L. 1997. Reproductive and genetic consequences of forest fragmentation: two case studies of neotropical canopy trees. Journal of Heredity 88: 264-276.

Ng, K. K. S.; Lee, S. L. \& Koh, C. L. 2004. Spatial structure and genetic diversity two tropical tree species with contrasting breeding systems and different ploidy levels. Molecular Ecology 13: 657-669.

Oliveira Filho, A. T. \& Ratter, J. A. 1995. A study of the origin of central Brazilian forests by the analysis of the plant species distributions. Edinburgh Journal of Botany 52: 141-194.

Pither, R.; Shore, J. S. \& Kellman, M. 2003. Genetic diversity of the tropical tree Terminalia amazonia (Combretaceae) in naturally fragmented populations. Heredity 91: 307-313.

Rohlf, F. J. 1989. Numerical taxonomy and multivariate analysis system, version 2.1. Exeter Publishing, Setauket, New York.

Sezen, U. U.; Chazdon, R. L. \& Holsinger, K. E. 2005. Genetic consequences of tropical second-growth forest regeneration. Science 307: 11.

Soliva, M. \& Widmer, A. 1999. Genetic and floral divergence among sympatric populations of Gymnadenia conopsea S.L. (Orchideaceae) with different flowering phenology. International Journal of Plant Sciences 160: 897-905.

Storfer, A.; Murphy, M. A.; Evans, J. S. et al. 2007. Putting the landscape in landscape genetics. Heredity 98: 128-142.

Swofford, D. L. \& Selander, R. B. 1989. Biosys-2: a computer program for the analysis of allelic variation in population genetics and biochemical systematics. Release 1.7, Illinois Natural History Survey, Champaign.

Van Treuren, R.; Bijlsma, R.; Ouborg, N. J. \& Van Delden, W. 1993. The effects of population size and plant density on outcrossing rates in locally endangered Salvia pratensis. Evolution 47: 1094-1104.

Vieira, F. A. \& Carvalho, D. 2008. Genetic structure of an insect-pollinated and bird-dispersed tropical tree in vegetation fragments and corridors: implications for conservation. Biodiversity and Conservation, 17: 2305-2321.

Weir, B. S. \& Cockerham, C. C. 1984. Estimating $F$-statistics for the analysis of population structure. Evolution 38: 1358-1370.

Wendel, J.F. \& Weeden, N.F. 1989. Visualization and interpretation of plant isozymes. In D. E. Soltis and P. S. Soltis [eds.], Isozymes in plant biology, 5-45. Dioscorides Press, Portland, Oregon, USA.

White, G. M., Boshier D. H. \& Powell W. 2002. Increased pollen flow counteracts fragmentation in a tropical dry forest, an example from Swietenia humilis Zuccarini. Proceedings of the National Academy Science of the USA 99: 2038-2042.

Wright, S. 1943. Isolation by distance. Genetics 28: 114-138. 